\title{
Pengaruh Letak Posisi Eksplan dan Sitokinin Pada Perkecambahan Biji Manggis (Garcinia mangostana L.) Lokal Aceh Secara in-Vitro
}

\author{
The Influence of Position of Explants and Cytokinin At Germination of \\ Local Mangosteen Seeds (Garcinia mangostana L.) in Aceh by In-Vitro
}

\author{
Rd. Selvi Handayani, Maisura, dan Astia Rizki \\ Jurusan Agroteknologi Fakultas Pertanian Universitas Malikussaleh \\ Muara Batu Lhokseumawe
}

\begin{abstract}
Abstrak
Untuk meningkatkan keragaman genetik manggis harus dilakukan dengan cara bioteknologi modern. Kultur jaringan pada manggis merupakan hal yang penting dilakukan untuk menunjang program bioteknologi tanaman manggis. Tujuan penelitian ini untuk mengetahui pengaruh letak posisi eksplan dan konsentrasi Benzil Amino Purin (BAP) pada perkecambahan manggis lokal Aceh secara in vitro. Penelitian ini dilaksanakan di Laboraturium Kultur Jaringan Fakultas Pertanian Universitas Malikussaleh. Penelitian dilaksanakan dari bulan Maret sampai dengan bulan Mei 2017. Penelitian ini menggunakan rancangan lingkungan berupa Rancangan Acak Lengkap (RAL) dengan dua faktor perlakuan. Faktor pertama adalah letak posisi eksplan yaitu letak abaksial / luka menghadap media (L1) dan adaksial / luka membelakangi media (L2). Faktor kedua adalah konsentrasi BAP 0 mg/L (B0), 2,5 mg/L (b1), dan 5 $\mathrm{mg} / \mathrm{L}$ (B2). Hasil penelitian menunjukkan bahwa letak posisi eksplan berpengaruh pada perkecambahan manggis secara in vitro untuk peubah panjang tunas. Posisi eksplan yang memberi pengaruh terbaik pada pertumbuhan kecambah manggis in vitro adalah adaksial. Konsentrasi BAP berpengaruh pada perkecambahan manggis secara in vitro untuk peubah waktu tumbuh tunas dan persentase hidup. Konsentrasi BAP 2,5 ppm merupakan konsentrasi terbaik untuk pertumbuhan kecambah manggis secara in vitro. Tidak ada interaksi antara posisi eksplan dan konsentrasi BAP disemua peubah yang diamati.
\end{abstract}

Kata Kunci: Biji, eksplan, in-vitro, sterilisasi, tunas

\begin{abstract}
The application of modern biotechnology is needed in order to enhance the genetic diversity of mangosteens. The application of tissue culture on mangosteens is an important thing to do to support the biotechnology program of mangosteen plants. The purpose of this research is to reveal the influence of location of explants and Benzylaminopurine (BAP) concentration on germination of local Acehnese mangosteens in vitro. This research was conducted at the Laboratory of tissue culture of the Faculty of Agriculture, Malikussaleh University from March to May 2017. The study used an environmental design in the form of Completely Randomized Design (CRD) with two factors. The first factor is the location of explant position is abaxial (L1) and adaxial (L2). The second factor was the concentration of BAP $0 \mathrm{mg} /$ $\mathrm{L}$ (B0), $2.5 \mathrm{mg} / \mathrm{L}$ (b1), and $5 \mathrm{mg} / \mathrm{L}$ (B2). The results showed that the position of eksplan gave an effect on mangosteen germination in vitro for its shoot length variables. The explant positions that had the best effect on the growth of in vitro mangosteen sprouts were adaxial. BAP concentration had an effect on germination of mangosteen in vitro for its bud growth and life percentage. $2.5 \mathrm{ppm}$ of BAP concentration was the best concentration for mangosteen seed growth in vitro. There was no interaction between eksplan position and BAP concentration in all observed variables.
\end{abstract}

Keywords: Seeds, explants, in-vitro, sterilization, buds

\section{Pendahuluan}

Manggis (Garcinia mangostana L.) merupakan komoditas buah asli Indonesia yang mempunyai prospek sangat baik untuk dikembangkan. Manggis merupakan salah satu buah tropis yang sangat terkenal, dan disebut sebagai Queen of Fruits karena rasa buahnya yang lezat dan banyak digemari. Selain itu, manggis juga dimanfaatkan sebagai obat-obatan 
diantaranya sebagai anti inflamasi, anti bakteri dan sebagai perlakuan terhadap infeksi dan luka (Widiastuti et al., 2013).

Produksi manggis di Provinsi Aceh pada Tahun 2012 sebesar 23.057 kuintal (Badan Pusat Statistik, 2013), dengan daerah produksi tersebar di 18 Kabupaten/Kota. Daerah utama penghasil buah manggis di Provinsi Aceh adalah Kabupaten Aceh Timur, Aceh Utara, dan Pidie Jaya. Daerah sentra manggis di Aceh kabupaten Pidie Jaya yang mendapat peringkat ke tiga setelah Aceh Timur dan Aceh Utara (Badan Pusat Statistik, 2013).

Tanaman manggis sudah dikenal berabad-abad yang lalu, namun masih banyak yang belum membudidayakannya. Hal ini disebabkan karena pertumbuhannya yang lambat. Selain itu biji manggis hanya tersedia pada musim tertentu ketika musim berbuah (1-2 kali setahun). Setiap buah hanya menghasilkan 1-2 biji yang berukuran besar dan yang layak untuk dijadikan benih. Tanaman manggis secara alami berbuah setelah berumur $12-15$ tahun (Ashari dan Sunarsih, 2006). Pertumbuhan tanaman manggis yang lambat berkaitan erat dengan sistem perakaran. Tanaman manggis mempunyai akar tunggang yang panjang dan kuat, tetapi percabangan akarnya sangat sedikit, dan hamper tidak memiliki bulu akar. Hal ini menimbulkan masalah serius pada proses penyerapan air dan unsur hara dari dalam tanah.

Biji manggis bersifat apomitik, yaitu biji yang terjadi bukan dari hasil peleburan sel kelamin jantan dan betina, sehingga perbaikan sifat tidak dapat dilakukan secara generatif (melalui persilangan tanaman). Salah satu usaha peningkatan sistem perakaran manggis adalah melalui bioteknologi modern yaitu irradiasi sinar gamma untuk meningkatkan keragaman tanaman (Qosim, 2015). Hasil perlakuan irradiasi sinar gamma harus dilanjutkan dengan perbanyakan secara kultur jaringan tanaman (in vitro). Oleh karena itu, kultur jaringan pada manggis merupakan hal yang penting dilakukan untuk menunjang bioteknologi tanaman manggis.

Kultur jaringan tanaman adalah metode mengisolasi bagian tanaman (organ, jaringan, sel, protoplas) dan menumbuhkannya dalam kondisi aseptik, sehingga bagian-bagian tanaman tersebut dapat memperbanyak diri dan beregenerasi menjadi tanaman lengkap. Cara perbanyakan ini memiliki kelebihan dibandingkan perbanyakan yang lain karena semua bagian tanaman dapat ditumbuhkan menjadi tanaman yang utuh. Teknik kultur jaringan tanaman juga dapat menghasilkan bibit dalam jumlah banyak dalam waktu yang relatif singkat dibandingkan cara perbanyakan lain. Bagian tanaman yang digunakan sebagai eksplan dapat berupa tunas pucuk, potongan batang satu buku (nodal eksplan), potongan akar, potongan daun dan bagian bunga (Yusnita, 2003), biji dan tunas mikro (Handayani et al., 2013).

Penanaman manggis in vitro dapat dilakukan dengan teknik perkecambahan poliembrio, yaitu pada satu biji manggis dilakukan proses pembelahan biji. Hal ini dilakukan untuk melihat perbedaan antara posisi eksplan dan untuk memisahkan embrio-embrio yang ada dalam satu biji. Berdasarkan penelitian sebelumnya pada tanaman manggis diketahui bahwa dengan adanya variasi potongan biji mampu dihasilkan jumlah bibit tanaman yang lebih banyak. Biji dapat dibelah dan ditanamkan pada beberapa posisi eksplan pada media (Ihsan dan Sukarmin, 2011).

Salah satu faktor penentu keberhasilan kultur jaringan adalah pemberian Zat Pengatur Tumbuh (ZPT). ZPT yang biasa digunakan untuk perkecambahan tunas tanaman adalah Sitokinin. Salah satu golongan sitokinin sintetik yang biasa digunakan pada teknik kultur jaringan adalah Benzil Amino Purin (BAP). BAP adalah golongan hormon sitokinin sintetik yang aktif dan daya rangsangnya lebih lama karena tidak mudah dirombak oleh tanaman. Selain itu, BAP juga merupakan jenis golongan ZPT yang sering digunakan karena paling efektif untuk merangsang pembentukan tunas, lebih stabil dan tahan terhadap oksidasi serta lebih murah dibandingkan jenis sitokinin sintetik lainnya (George dan Sherrington (1984) dalam Andaryani, 2010).

Hasil penelitian di Balitbio Bogor pada tahun 1999 menunjukkan bahwa pemberian BAP $5 \mathrm{mg} / \mathrm{l}$ pada media pertunasan memberikan jumlah tunas yang lebih banyak daripada pemberian BAP $2 \mathrm{mg} / \mathrm{l}$ (Supriati et al., 2000). Sebaliknya untuk pertumbuhan tunas manggis BAP $3 \mathrm{mg} / \mathrm{l}$ menyebabkan pertumbuhan yang lebih baik daripada BAP $5 \mathrm{mg} / \mathrm{l}$ (Supriati et al., 2001).

\section{Bahan dan Metode}

Penelitian ini dilaksanakan di Laboraturium Kultur Jaringan Fakultas Pertanian Universitas Malikussaleh. Penelitian 
dilaksanakan dari bulan Maret sampai dengan bulan Mei 2017.

Bahan yang digunakan dalam penelitian ini adalah biji manggis yang berasal dari Kota Lhokseumawe, alkohol, bayclin, fungisida dan bakterisida, gula pasir, spirtus, agar-agar, aquades steril, plastik bening, karet gelang, kertas buram, media MS dan BAP. Alat yang digunakan dalam penelitian ini adalah gelas piala ukuran $100 \mathrm{ml}$ dan $1000 \mathrm{ml}$, timbangan analitik, botol ukur, gelas ukur, cawan petri, lampu bunsen, pipet, scalpel, pengaduk, kulkas, $\mathrm{pH}$ meter, Laminar Air Flow Cabinet (LAFC), autoclave, hotplate, magnetik stirer, dan kamera digital.

Penelitian ini menggunakan rancangan lingkungan berupa Rancangan Acak Lengkap (RAL) dengan dua faktor perlakuan. Faktor pertama adalah letak posisi eksplan yaitu letak abaksial / luka menghadap media (L1) dan adaksial / luka membelakangi media (L2). Faktor kedua adalah konsentrasi BAP 0 mg/L (B0), 2,5 $\mathrm{mg} / \mathrm{L}$ (b1), dan $5 \mathrm{mg} / \mathrm{L}$ (B2). Jumlah perlakuan ada 6 dengan 10 ulangan, sehingga didapatkan 60 satuan percobaan.

\section{Sterilisasi Eksplan}

Biji manggis segar dilepaskan dari selaput berserat tempat menempelnya daging buah. Biji dibersihkan arilnya, kemudian dipilih yang besar dan beratnya hampir seragam $(\geq 0,8 \mathrm{~g})$. Biji kemudian dicuci dengan air deterjen encer selama 10 menit, lalu dibilas dan dimasukkan ke Laminar Air Flow (LAF). Eksplan (biji manggis) lalu direndam dengan fungisida bakterisida sebanyak 0,8 g/l selama 30 menit. Biji dibilas dengan aquades streril beberapa kali sampai bersih, lalu direndam dalam alhohol $70 \%$ selama 5 menit dan dibilas dengan aquades steril sebanyak 1 kali. Eksplan direndam dalam larutan bayclin $30 \%$, 20\%, dan 10\%, masing-masing selama 15, 20 dan 25 menit, lalu dibilas aquades steril.

\section{Penanaman Eksplan}

Eksplan biji manggis yang sudah disterilisasi, kemudian diletakkan di cawan petri yang dilapisi oleh kertas steril. Biji manggis dibelah menjadi 4 bagian, kemudian ditanam ke dalam media tanam sesuai perlakuan. Setiap botol kultur 4 eksplan. Botol kultur ditutup dengan rapat, diberi label, dan disimpan di ruang inkubasi pada suhu $24-26^{\circ} \mathrm{C}$.

\section{Pengamatan dan analisis data}

Pengamatan dilakukan pada beberapa peubah, yaitu waktu tumbuh tunas, panjang tunas, waktu tumbuh akar, jumlah akar, jumlah daun, persentase keberhasilan. Pengamatan dilakukan selama 8 minggu. Data dianalisis secara statitisk dengan menggunakan Analisis Ragam (Anova). Data yang menunjukkan perbedaan nyata pada Anova 5\% dilakukan analisis lanjut dengan Uji Jarak Berganda Duncan (UJBD). Analisis statistik dilakukan menggunakan software SAS ver9.12.

\section{Hasil dan Pembahasan \\ Hasil}

Berdasarkan hasil pengamatan, didapatkan bahwa tidak terdapat interaksi antara perlakuan letak posisi eksplan (L) dan konsentrasi BAP (B). Pengaruh masing-masing perlakuan secara tunggal terlihat pada peubah waktu tumbuh tunas, panjang tunas, dan persentase tumbuh tunas. Data hasil uji lanjut pengaruh letak posisi eksplan dan konsentrasi BAP terhadap peubah waktu tumbuh tunas, panjang tunas, dan persentase tumbuh tunas pada perkecambahan biji manggis secara in vitro disajikan pada Tabel 1.

Tabel 1 menunjukkan bahwa pemberian eksplan yang ditanam secara adaksial memiliki panjang tunas lebih baik daripada secara abaksial. Pada peubah lainnya yaitu waktu tumbuh tunas dan persentase tumbuh tunas, kedua posisi eksplan tidak memberikan perbedaan. 
Tabel 1. Pengaruh letak posisi eksplan dan konsentrasi BAP terhadap waktu tumbuh tunas, panjang tunas, dan persentase tumbuh tunas pada perkecambahan biji manggis secara in vitro.

\begin{tabular}{cccc} 
Perlakuan & $\begin{array}{c}\text { Waktu Tumbuh } \\
\text { Tunas (HST) }\end{array}$ & Panjang Tunas (cm) & $\begin{array}{c}\text { Persentase Tumbuh } \\
\text { Tunas (\%) }\end{array}$ \\
\hline
\end{tabular}

Letak Posisi Eksplan :

Abaksial (L1)

Adaksial (L2)

$$
11,77(3,45) \text { a }
$$$$
11,54(3,43) \text { a }
$$

$$
2,00(1,57) \mathrm{b}
$$$$
3,18(1,90) \text { a }
$$

$68,18(8,21)$ a

$60,40(7,64)$ a

Konsentrasi BAP:

$0 \mathrm{mg} / \mathrm{L}(\mathrm{B} 0)$

$2,5 \mathrm{mg} / \mathrm{L}(\mathrm{B} 1)$

$5 \mathrm{mg} / \mathrm{L}(\mathrm{B} 2)$

$14,28(3,88) \mathrm{a}$
$11,00(3,33) \mathrm{ab}$
$9,71(3,15) \mathrm{b}$

$2,25(1,64) \mathrm{a}$

$59,37(7,69) b$

$3,00(1,85)$ a

$85,71(9,26)$ a

$2,83(1,80)$ a

Keterangan : Angka yang diikuti oleh huruf yang sama pada kolom yang sama tidak berbeda nyata berdasarkan uji DMRT pada taraf 0,05 . Angka dalam kurung adalah data hasil transformasi $\sqrt[2]{(x+0,5)}$.

Tabel 1 juga menunjukkan bahwa konsentrasi BAP 2,5 $\mathrm{mg} / \mathrm{L}$ ternyata menyebabkan eksplan tumbuh tunas lebih cepat dan persentase tumbuh tunasnya lebih tinggi dibandingkan perlakuan lainnya. Pada peubah panjang tunas meskipun secara statistik tidak menunjukkan perbedaan, namun secara rataan perlakuan BAP $2.5 \mathrm{mg} / \mathrm{L}$ menyebabkan panjang tunas terbaik.

Pengaruh masing-masing perlakuan secara tunggal pada peubah lainnya yaitu jumlah daun, persentase tumbuh akar, dan jumlah akar ternyata tidak menujukkan adanya perbedaan secara statisitik. Data hasil uji lanjut pengaruh letak posisi eksplan dan konsentrasi BAP terhadap peubah jumlah daun, persentase tumbuh akar, dan jumlah akar perkecambahan biji manggis secara in vitro disajikan pada Tabel 2 .

Tabel 2 menunjukkan bahwa secara statistik pengaruh masing-masing perlakuan secara tunggal pada jumlah daun, persentase tumbuh akar, dan jumlah akar tidak ada perbedaan. Nilai rataan secara umum eksplan yanag ditanam dengan posisi adaksial pertumbuhannya lebih baik, dan konsentrasi BAP $0 \mathrm{mg} / \mathrm{L}$ menyebabkan pertumbuhan eksplan lebih baik.

Tabel 2. Pengaruh letak posisi eksplan dan konsentrasi BAP terhadap jumlah daun, persentase tumbuh

\begin{tabular}{|c|c|c|c|c|}
\hline \multirow{2}{*}{ Perlakuan } & \multicolumn{2}{|c|}{ Jumlah Daun } & \multirow{2}{*}{$\begin{array}{c}\text { Persentase } \\
\text { Tumbuh Akar }\end{array}$} & \multirow[t]{2}{*}{ Jumlah Akar } \\
\hline & 6 MST & 7 MST & & \\
\hline & \multicolumn{2}{|c|}{------------------ helai ------------------ } & $\%$ & \\
\hline Letak Posisi Eksp & & & & \\
\hline Abaksial (L1) & $3,77(2,06) \mathrm{a}$ & $4,33(2,17) \mathrm{a}$ & $66(1,27) \mathrm{a}$ & $1,000 \mathrm{a}$ \\
\hline Adaksial (L2) & $3,63(2,02)$ a & $4,18(2,13) \mathrm{a}$ & $75(1,31)$ a & $1,000 \mathrm{a}$ \\
\hline \multicolumn{5}{|l|}{ Konsentrasi BAP: } \\
\hline $0 \mathrm{mg} / \mathrm{L}(\mathrm{B} 0)$ & $3,62(2,02) \mathrm{a}$ & $3,75(2,05) \mathrm{a}$ & $87(1,36) \mathrm{a}$ & $1,000 \mathrm{a}$ \\
\hline $2,5 \mathrm{mg} / \mathrm{L}(\mathrm{B} 1)$ & $3,50(1,98) a$ & $4,50(2,18) \mathrm{a}$ & $62(1,25) \mathrm{a}$ & $1,000 \mathrm{a}$ \\
\hline 5 mg/L (B2) & $4,00(2,12) \mathrm{a}$ & $4,66(2,26) \mathrm{a}$ & $62(1,25) \mathrm{a}$ & $1,000 \mathrm{a}$ \\
\hline
\end{tabular}
akar, dan jumlah akar pada perkecambahan biji manggis secara in vitro.

Keterangan : Angka yang diikuti oleh huruf yang sama pada kolom yang sama tidak berbeda nyata berdasarkan uji DMRT pada taraf 0,05 . Angka dalam kurung adalah data hasil transformasi $\sqrt[3]{(x+0,5)}$. 
Perkecambahan biji manggis mulai terjadi setelah 7 hari setelah tanam (HST). Eksplan manggis yang berasal dari biji manggis dibelah empat dapat tumbuh tunas lebih dari 1, bahkan pada kondisi tertentu dapat tumbuh banyak tunas. Eksplan yang memiliki banyak tunas tidak baik untuk dijadikan sumber tanaman pada tahap pertumbuhan selanjutnya, karena ukuran tunas menjadi lebih kecil dibandingkan tunas normal (Gambar 1).

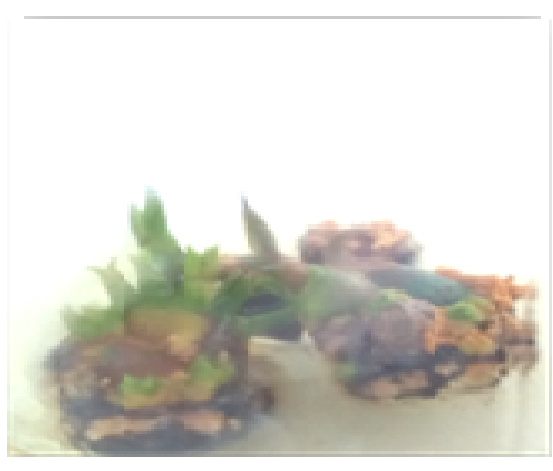

tumbuh 1 tunas (b).

Gambar
1.Tunas
yang
tumbuh
pada
eksplan.
Eksplan
yang
tumbuh
banyak
tunas (a);
eksplan
yang hanya

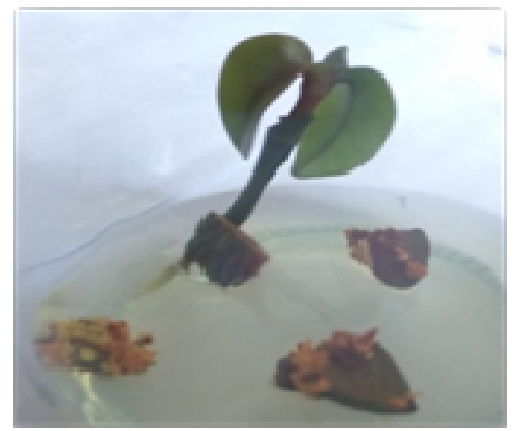

Eksplan manggis lokal asal Aceh memiliki warna daun yang berbeda saat baru berkecambah dan setelah tumbuh menjadi daun dewasa. Saat pertama kali mekar (fase pertumbuhan daun muda), daun manggis berwarna merah keunguan, dan warna akan berubah menjadi hijau seiring pertumbuhan daun (Gambar 2). Eksplan yang ditanam pada posisi abaksial biasanya akan menghasilkan tunas yang lebih banyak.

Gambar 2. Perubahan warna daun manggis seiring pertumbuhan daun. Fase daun mekar berwarna merah kecoklatan (a); daun muda berwana hijau muda (b); daun dewasa berwarna hijau tua (c).
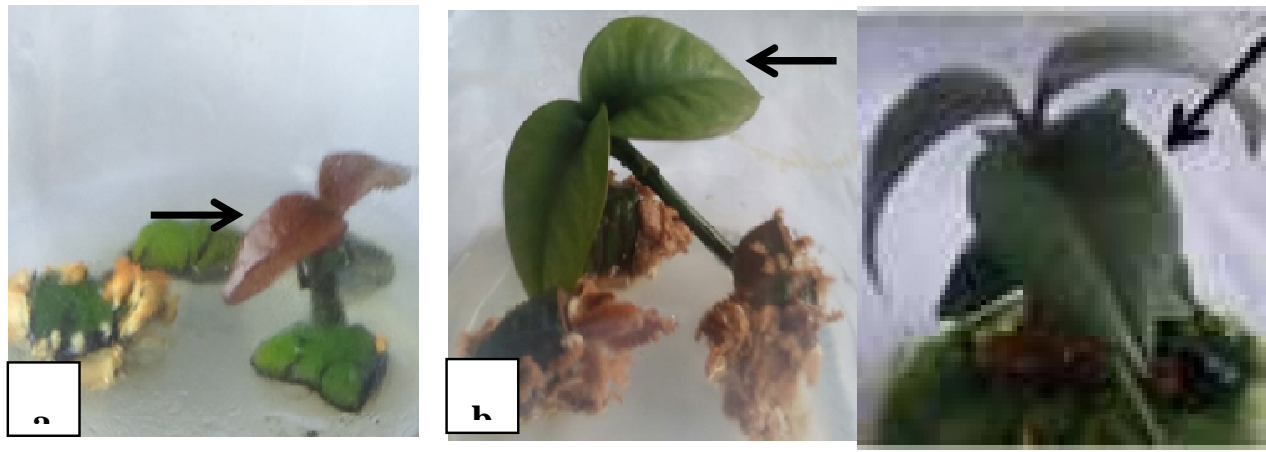


\section{Pembahasan}

Penelitian ini menggunakan letak posisi eksplan yang berbeda yaitu secara abaksial (L1) dan posisi adaksial (L2). Posisi eksplan adaksial memberikan pengaruh lebih baik secara statistik pada peubah panjang tunas, dibandingkan posisi abaksial. Perlakuan eksplan pada posisi adaksial secara rataan juga memberikan pengaruh lebih baik daripada posisi abaksial pada peubah waktu tumbuh tunas dan persentase tumbuh akar (Tabel 1 dan 2).

Letak posisi eksplan secara abaksial adalah bagian eksplan yang terkena luka akibat pemotongan biji menghadap media (telungkup), sedangkan letak posisi adaksial yaitu bagian eksplan yang tidak terkena luka menghadap media (telentang). Eksplan dengan posisi abaksial lebih cepat menyerap unsur hara yang terkandung pada media, karena luas permukaan bagian luka lebih banyak kontak langsung dengan media. Hal ini dapat menyebabkan eksplan manggis posisi abaksial menghasilkan tunas lebih banyak sehingga terkadang pertumbuhan tunas menjadi roset dan hanya satu tunas saja yang biasanya akan tumbuh (Handayani, 2012). Pertumbuhan tanaman roset menyebabkan terjadinya persaingan hara diantara tunas-tunas yang tumbuh. Oleh karena itu, pada penelitian ini pertumbuhan tunas pada posisi adaksial lebih baik daripada abaksial.

Pemotongan eksplan juga menyebabkan eksplan mengalami luka. Biji yang mengalami pemotongan akan menghasilkan jumlah tunas yang lebih banyak daripada biji utuh (Ihsan dan Sukarmin (2011). Biji dibelah memiliki jumlah tunas yang tinggi. Biji manggis yang dibelah dengan posisi telungkup dan bagian luka menghadap media menyebabkan terjadi kontak langsung antara media dengan biji manggis yang dilukai (Romeida 2007). Pemotongan biji juga menyebabkan terjadi kontak antara permukaan biji dan media yang mengandung hara dan zat pengatur tumbuh tanaman,

Pembelahan biji menyebabkan dominansi apikal eksplan biji manggis hilang, terutama karena adanya pelukaan akibat pemotongan biji. (Handayani et al., 2013). Hal ini disebabkan karena hilangnya dominasi apikal yang menyababkan pertumbuhan tunas samping. Biji manggis adalah biji apomiksis, tunas manggis terbentuk dari sel-sel embriogenik yang berada di daerah jaringan nuselus. Sel-sel embriogenik jumlahnya sangat banyak sehingga dalam kondisi memungkinkan eksplan dapat menumbuhkan banyak tunas.

Munculnya tunas ditandai dengan terbentuknya tonjolan atau kuncup berwarna hijau pada permukaan biji tanaman manggis yang lama kelamaan akan membesar kemudian muncul primordia daun pada ujung tonjolan. Hasil percobaan menunjukkan bahwa tidak semua eksplan membentuk tunas. Hal ini disebabkan karena eksplan tumbuh kalus, sehingga terjadi persaingan energi untuk pembentukan tunas.

Letak posisi eksplan tidak berpengaruh pada persentase tumbuh akar dan jumlah akar. Hal ini diperkirakan karena eksplan manggis lebih dominan menyerap unsur hara untuk pembentukan tunas.

Faktor konsentrasi BAP secara statistik berpengaruh terhadap peubah waktu tumbuh tunas dan persentase tumbuh tunas. Eksplan yang ditanam pada media MS ditambah BAP 2,5 $\mathrm{mg} / \mathrm{L}$ menyebabkan tunas tumbuh lebih cepat dan memiliki persentase pertumbuhan tunas lebih baik daripada perlakuan lainnya (Tabel 1). Pada peubah lainnya konsentrasi BAP tidak memberikan pengaruh nyata secara statistik (Tabel 2).

BAP merupakan zat pengatur tumbuh golongan sitokinin. Pemberian zat pengatur tumbuh sitokinin berpengaruh terhadap pertumbuhan tunas dan dapat menyebabkan tunas tumbuh lebih cepat. Konsentrasi sitokinin yang tinggi lebih cocok diaplikasikan untuk perkembangan, pelipatgandaan dan pertumbuhan tunas pada eksplan. BAP merupakan golongan sitokinin aktif yang bila diberikan pada tunas akan mendorong proliferasi tunas yaitu keluarnya tunas lebih dari satu (Yusnita, 2003).

Pemberian BAP $5 \mathrm{mg} / \mathrm{L}$ ternyata kurang memberi pengaruh baik pada pertumbuhan kecambah manggis in vitro (Tabel 1). Hal ini diduga karena pada konsentrasi BAP $5 \mathrm{mg} / \mathrm{L}$ kandungan sitokinin menjadi tinggi sehingga menyebabkan terhambatnya pertumbuhan tunas pada eksplan. ZPT hanya efektif pada konsentrasi tertentu, konsentrasi yang terlalu tinggi dapat menghambat perkecambahan (Hartmann et al., 2002).

Pada eksplan manggis asal Bengkalis perlakuan $3 \mathrm{mg} / \mathrm{L}$ BAP menghasilkan jumlah tunas tertinggi dibandingkan perlakuan lainnya. Pemberian BAP 2 ppm memberikan tinggi tunas tanaman buah naga yang baik (Trisnahati, 2007). Pemberian BAP 2 ppm dan 4 ppm memberikan 
pertumbuhan eksplan gingseng jawa yang relatif baik (Isharyati, 1999).

Pemberian BAP tidak berpengaruh nyata pada peubah persentase dan jumlah akar. Pembentukan akar manggis sangat sulit terjadi. Hal ini disebabkan karena manggis memiliki sifat perakaran yang sangat lemah. Pengakaran pada manggis mudah patah, lambat tumbuh, dan mudah terganggu karena tidak dijumpai akar rambut pada akar utama maupun akar lateral. Tanaman manggis termasuk tanaman yang tidak memiliki (sedikit) bulu-bulu akar, sehingga kemampuan menyerap air dan hara terbatas. Sehingga jumlah akar yang muncul pada eksplan biji manggis mendapatkan hasil yang sedikit. Tidak terbentuknya akar pada tunas mempengaruhi penyerapan unsur hara untuk pembentukan daun (Isda et al., 2016).

Eksplan tanpa pemberian BAP juga berhasil tumbuh tunas meskipun lebih lambat. Hal ini membuktikan bahwa suatu organ dan jaringan tumbuhan mengandung hormon endogen yang dapat mempengaruhi pertumbuhan dan perkembangan organ atau jaringan tersebut hingga tahapan yang paling sempurna walaupun tidak ditambahkan zat pengatur tumbuh dari luar. media MS umum digunakan untuk induksi tunas dan mengandung nutrisi yang sesuai untuk menunjang pertumbuhan optimal dari tanaman secara in vitro (Razdan 2003).

Banyak kendala dalam pembibitan tanaman manggis, baik secara in vitro maupun ex vivo. Kendala yang dihadapi misalnya produksi biji layak tanam yang rendah dan sifat biji rekalsitran (Qosim, 2004), pertumbuhan tanaman sangat lambat dan lemah serta perakaran yang sangat sedikit (Harahap et al., 2014). Oleh sebab itu, budidaya secara in vitro dengan penambahan zat pengatur tumbuh perlu dilakukan lebih intensif, agar mengoptimalkan hasil pertumbuhan tanaman manggis.

\section{Kesimpulan}

Dari hasil penelitian ini dapat disimpulkan sebagai berikut:

1. Letak posisi eksplan berpengaruh pada perkecambahan manggis secara in vitro untuk peubah panjang tunas. Posisi eksplan yang memberi pengaruh terbaik pada pertumbuhan kecambah manggis in vitro adalah adaksial.

2. Konsentrasi BAP berpengaruh pada perkecambahan manggis secara in vitro untuk peubah waktu tumbuh tunas dan persentase hidup. Konsentrasi BAP 2,5 ppm merupakan konsentrasi terbaik untuk pertumbuhan kecambah manggis secara in vitro.

3. Tidak ada interaksi antara posisi eksplan dan konsentrasi BAP disemua peubah yang diamati.

\section{Daftar Pustaka}

Ashari dan Sunarsih. 2006. Manggis Komoditas Unggulan Tasikmalaya. Warta Penelitian dan Pengembangan Pertanian. 28 (1) : 27-28.

[BPS ] Badan Pusat Statistik. 2013. Statistik Indonesia. Badan Pusat Statistik, Aceh Utara.

George, E.F and Sherington, P.D. 1984. Plant Propogation by Tissue Culture Exegetics Limited. England.

Handayani, R.S. 2012. Rekayasa teknologi sambung mikro dan setek mikro pada tanaman manggis (Garcinia mangostana). [disertasi]. Bogor: Institut Pertanian Bogor, Program Pascasarjana. 127 hal.

Handayani, R.S., Poerwanto, R., Sobir, Purwito, A., Ermayanti, TM. 2013. Pengaruh Batang Bawah dan Jenis Tunas Pada Mikrograftting Manggis (Garcinia mangostana L.) Secara In Vitro. J. Agron. Indonesia. 41 (1) : 47-53.

Harahap, F., Poerwanto, P., Suharsono, Suriani, C., \& Rahayu, S. (2014). In vitro growth and rooting of mangosteen (Garcinia mangostana 1.) on medium with different concentration of plant growth regulator. HAYATI Journal of Biociences, 21 (4), 151-158.

Hartmann HT, Kester DE, Davies FT, Geneve RL. 2002. Plant Propagation Principal and Practise. Pearson Education Inc.New Jersey: Upper Saddle River.

Ihsan, F. dan Sukarmin. 2011. Teknik pengujian pembelahan biji terhadap efektifitas perbanyakan manggis (Garcinia mangostana L.) melalui biji.

Isda, M. N. 2009. Induksi Kalus Centella asiatica Melalui Aplikasi Auksin dan Sitokinin. Jerami 2(3) : 162-165.

Isharyati, 1999. Pengaruh Kadar NAA dan BAP terhadap Pertumbuhan Eksplan Ginseng Jawa (Talinum paniculatum) secara in vitro. Skripsi S1. Fakultas Pertanian Universitas Muhammadiyah. Yogyakarta. 
Qosim, W. A. 2004. Pemuliaan Manggis tak Sesulit Dibayangkan. Diakses dari www.pikiran-

rakyat.com/cetak/1204/cakrawala/lainnya 4.htm. Tanggal 15 Desember 2016.

Qosim, W.A., Yuwariah, Y., Hamdani, J.S., Rachmadi, M. 2015. Pengaruh Mutagen Etil Metan Sufonat Terhadap Regenerasi Tunas Pasa Dua Genotip Manggis Asal Purwakarta dan Pandeglang. J. Hort. 25 (1) : 9-14.

Razdan, M.K. 2003. Introduction to Plant Tissue Culture. $2^{\text {nd }}$ Edition. Science Publisher, Inc. 377 hal.

Romeida A. 2007. Respon berbagai tipe eksplan biji manggis (Garcinia mangostana L.) pada beberapa konsentrasi benzyl amino purin (BAP) terhadap pembentukan dan regenerasi polyembrioninya secara in vitro. Jurnal Akta Agrosia. 10 (2): 162-166.
Supriati, Y., N. Sunarlim, W.H. Adil, I. Mariska, Y. Rusyadi, D. Sukmadjaja, E.G. Lestari, dan Murtado. 2001. Studi regenerasi tanaman potensial dan bernilai ekonomi tinggi. Laporan Hasil Penelitian Balitbio, Bogor.

Trisnahati, A. 2007. Pengaruh Jenis Media dan Konsentrasi BAP terhadap Multiplikasi Tanaman Buah Naga (Hylocereus polyrhizus) secara in vitro. Skripsi S1. Fakultas Pertanian Universitas Sebelas Maret. Surakarta.

Widiastuti, A.,Sobir.,Suhartanto, M.R. 2013. Analisis Keragaman Genetik Manggis (Garcinia mangostana L.) Diiradiasi Dengan Sinar Gamma Berdasarkan Penanda ISSR. J. Bioteknologi Vol 10 (1): 15-22.

Yusnita. 2003. Kultur Jaringan: Cara Memperbanyak Tanaman Secara Efisien. Agromedia Pustaka: Jakarta. 105 Hal. 